\title{
Study Wear Tool with High-speed Milling
}

\author{
Tsvetan Kaldashev, Petar Hadzhiyski, Galina Nikolcheva \\ Technical university of Sofia, Address: Blvd. "Kl. Ohridski” 8, Sofia, Bulgaria
}

\begin{abstract}
This report examined tool wear in high-speed machining of tool steel with a hardness of HRC 63. Wear monitored periodically using the device for automatic geometric correction tool (length and radius) situated in the working area of the machine. The study was conducted on milling machine RAIS M400 with CNC Heidenhain iTNC $530 i$.
\end{abstract}

Keywords: wear, high-speed milling, cutting tool, milling machine, CNC.

\section{I.INTRODUCTION}

Rotary dies for the production of sanitary absorbents (Figure 1) in the process of work wear $[1,2]$, which requires their periodic sharpening i.e. reconstruction of cutting power. They are made of tool steel, where after quenching reached hardness between 60 and 63 HRC. Resharpening of these components is carried out by grinding the side surface where the process compared to the milling has a low performance [3].

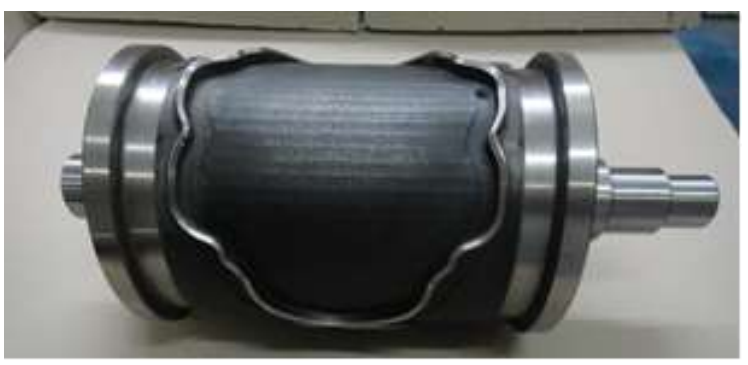

Fig. 1 Rotary die for sanitary absorbents

Taking into account the stiffness of the rotary die from HRC 63 e possible to increase productivity by using high-speed milling. When sharpening the cutting edge of the rotary die due to different wear have capture greater added. This, together with the great length of the cutting edge may lead in turn to an unacceptable wear of the cutting tool and breakage. The aim of the study is to check the wear of the tool to be able to answer the question whether high-speed milling can replace grinding.

\section{STUDY OF THE WEAR OF THE TOOL AT HIGH SPEED MILLING}

To conduct the study used a cutting tool company SGS Series Power-Carb with AlTiN coating. This series is recommended for machining of molds for injection molding of forms for casting and the production of dies [4, 5]. Tools of this series are characterized by high quality of the machined surface of hardened steel with a hardness of 65 HRC. The study is done on milling machine RAIS M400 with CNC Heidenhain iTNC 530i [6]. Fig. 2 shows the establishment of a workpiece, which is essentially a rotary die obsolete.
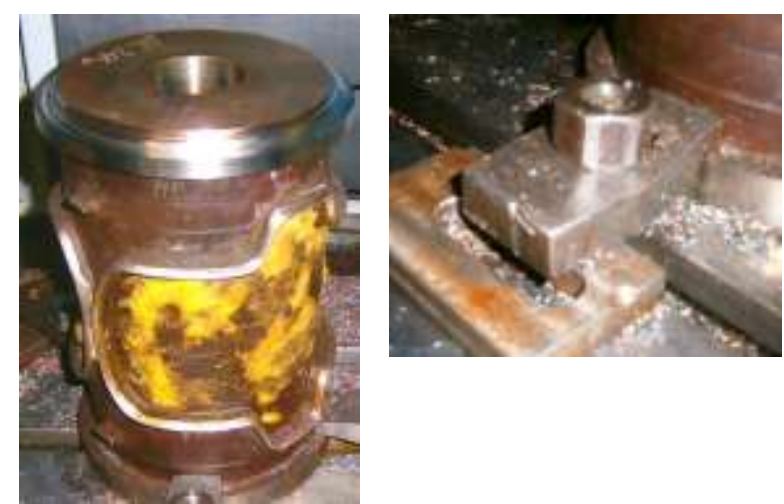

Fig. 2 Establish a workpiece

Wear on the tool radius is controlled using the findings in the working area of the machine device for automatically determining the length and tool radius (Tool Touch Probe TT140). This is a built-in CNC cycles. The measurement of the tool radius is performed with cycle 482 (Fig.3), wherein the measurement is possible to carry out in two ways with continuous rotation of the instrument and measurement of each tooth separately, in which case it must first be set to the number of the teeth of the tool. In this way, the system automatically determines the highest tooth and it introduces a correction. After measurement, the values recorded in the subinstruments.

\section{Study of measurement accuracy Tool Touch} Probe TT140

The study of the accuracy of the TT 140 is necessary to examine to what extent will be reliable survey data. It will be held by being made 20 measurements for each of the aforementioned methods. http://dx.doi.org/10.17770/etr2017vol3.2598 


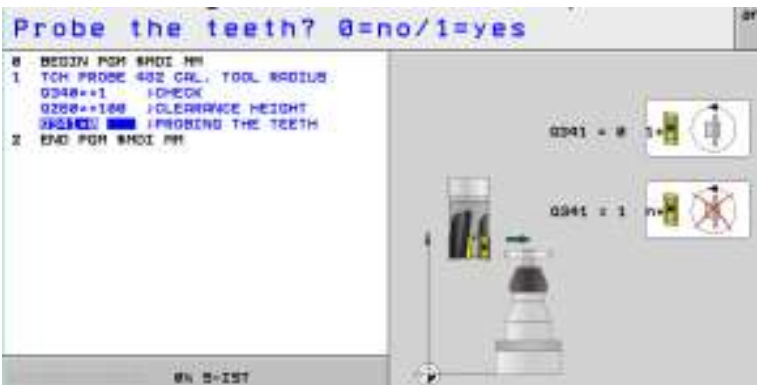

Fig. 3 Measuring cycle 482

\section{Accuracy in the rotating tool}

Used measurement cycle 482 (fig. 3). This cycle is only measured tool radius. Depending on what is set in parameter 341 (fig. 3) measured on the rotating tool (parameter $341=0$ ) or measured each tooth individually (parameter $341=1$ ). In Table 1 shows the measurement results.

Table 1

Results of measurement in rotating too

\begin{tabular}{|c|c|c|c|c|c|}
\hline № & $\begin{array}{c}\text { Tool } \\
\text { radius } \\
{[\mathrm{mm}]}\end{array}$ & $\begin{array}{c}\text { Deviations } \\
\text { DR [mm] }\end{array}$ & № & $\begin{array}{c}\text { Tool } \\
\text { radius } \\
{[\mathrm{mm}]}\end{array}$ & $\begin{array}{c}\text { Deviations } \\
\text { DR [mm] }\end{array}$ \\
\hline 1 & 4 & $-0,0155$ & 11 & 4 & $-0,0176$ \\
\hline 2 & 4 & $-0,0156$ & 12 & 4 & $-\mathbf{0 , 0 2 1 7}$ \\
\hline 3 & 4 & $-0,0219$ & 13 & 4 & $-0,0157$ \\
\hline 4 & 4 & $-0,0181$ & 14 & 4 & $-0,0210$ \\
\hline 5 & 4 & $-0,0104$ & 15 & 4 & $-0,0218$ \\
\hline 6 & 4 & $-\mathbf{0 , 0 2 2 7}$ & 16 & 4 & $-0,0165$ \\
\hline 7 & 4 & $-0,0247$ & 17 & 4 & $-0,0161$ \\
\hline 8 & 4 & $-0,0262$ & 18 & 4 & $-0,0108$ \\
\hline 9 & 4 & $-0,0225$ & 19 & 4 & $-0,0212$ \\
\hline 10 & 4 & $-0,0108$ & 20 & 4 & $-0,0134$ \\
\hline
\end{tabular}

Results are processed statistically to determine what is the accuracy of the measurement. Arithmetical mean value $\bar{\Delta}$ is defined by equation (1) and residual errors in equation (2).

$$
\begin{aligned}
& \bar{\Delta}=\frac{1}{n} \sum_{i=1}^{n} \Delta_{i} \\
& \delta_{i}=\Delta_{i}-\bar{\Delta}
\end{aligned}
$$

With the obtained values are determined standard deviation equation (3) and mean square deviation $\mathrm{S}_{\mathrm{X}}$ in equation (4).

$$
\begin{aligned}
& s=\sqrt{\frac{1}{n-1} \sum_{i=1}^{n} \delta_{i}^{2}}, \text { at } \mathrm{n}<30 \\
& s_{\bar{x}}=\frac{s}{\sqrt{n}}
\end{aligned}
$$

Confidence limits $\pm \varepsilon$ is defined in equation (5) at the confidence level $\gamma=0,99$, then determine confidence limits in equation (6).

$$
\begin{aligned}
& \varepsilon=t_{\gamma} \cdot s_{x} \\
& \left(\bar{X}-t_{\gamma} \cdot s_{\bar{X}}\right)<E<\left(\bar{X}+t_{\gamma} \cdot s_{\bar{X}}\right)
\end{aligned}
$$

The results are presented graphically in fig. 4 .

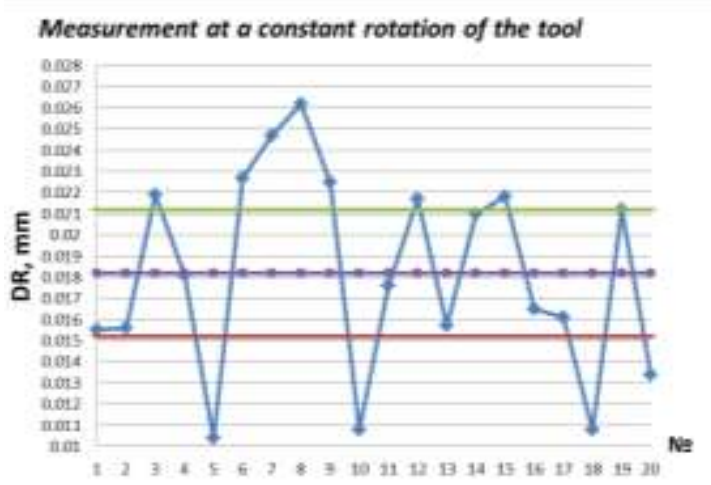

Fig. 4 Graphical representation of the accuracy of the rotating tool

\section{Accuracy of each tooth individually}

Again using the measuring cycle 482 as a parameter 341 is set to 1 . In the table parameters of the tool set number of teeth.

Table 2

Measurement results for each tooth individually

\begin{tabular}{|c|c|c|c|c|c|}
\hline № & $\begin{array}{c}\text { Tool } \\
\text { radius } \\
{[\mathbf{m m}]}\end{array}$ & $\begin{array}{c}\text { Deviations } \\
\text { DR [mm] }\end{array}$ & № & $\begin{array}{c}\text { Tool } \\
\text { radius } \\
{[\mathbf{m m}]}\end{array}$ & $\begin{array}{c}\text { Deviations } \\
\text { DR [mm] }\end{array}$ \\
\hline 1 & 4 & $\mathbf{- 0 , 0 1 6 6}$ & 11 & 4 & $\mathbf{- 0 , 0 1 7 2}$ \\
\hline 2 & 4 & $\mathbf{- 0 , 0 1 3 2}$ & 12 & 4 & $\mathbf{- 0 , 0 1 6 0}$ \\
\hline 3 & 4 & $\mathbf{- 0 , 0 1 3 4}$ & 13 & 4 & $\mathbf{- 0 , 0 1 7 0}$ \\
\hline 4 & 4 & $\mathbf{- 0 , 0 1 2 8}$ & 14 & 4 & $\mathbf{- 0 , 0 1 4 9}$ \\
\hline 5 & 4 & $\mathbf{- 0 , 0 1 4 1}$ & 15 & 4 & $\mathbf{- 0 , 0 1 3 3}$ \\
\hline 6 & 4 & $\mathbf{- 0 , 0 1 7 6}$ & 16 & 4 & $\mathbf{- 0 , 0 1 6 6}$ \\
\hline 7 & 4 & $\mathbf{- 0 , 0 1 6 8}$ & 17 & 4 & $\mathbf{- 0 , 0 1 6 8}$ \\
\hline 8 & 4 & $\mathbf{- 0 , 0 1 6 5}$ & 18 & 4 & $\mathbf{- 0 , 0 1 7 9}$ \\
\hline 9 & 4 & $\mathbf{- 0 , 0 1 6 0}$ & 19 & 4 & $\mathbf{- 0 , 0 1 7 4}$ \\
\hline 10 & 4 & $\mathbf{- 0 , 0 1 5 8}$ & 20 & 4 & $\mathbf{- 0 , 0 1 7 3}$ \\
\hline & & & & & \\
\hline
\end{tabular}

The measurement results are presented in Table. 2. In Fig. 5 presents graphically the data processed statistically by the equations (1) to (6).

The standard deviation of the first case (a rotating tool) is $\mathrm{S}=0.0047$, and in the second case, $\mathrm{S}=$ 0.0016. Mean square error in the measurement of rotation of the tool is $\mathrm{SX}=0.0011$, while the second case when measured each tooth individually, the mean square error is $\mathrm{SX}=0.0004$. 
Environment. Technology. Resources, Rezekne, Latvia Proceedings of the $11^{\text {th }}$ International Scientific and Practical Conference. Volume III, 117-121

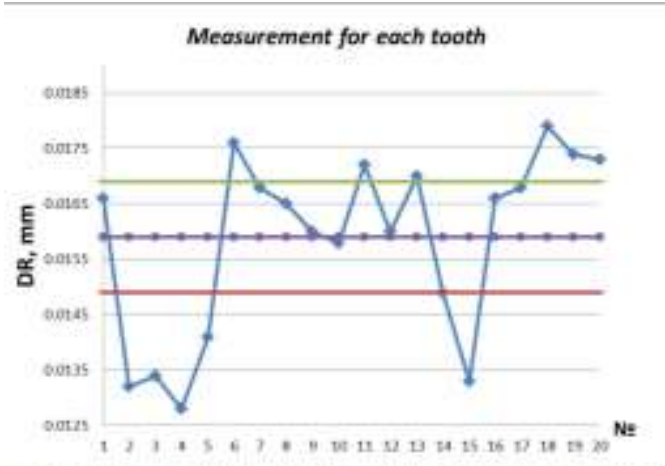

Fig. 5 Graphical representation of accuracy in measuring each tooth individually

From these results, it is found that the method which measures each cutting tooth individually is more accurate and will be used in the experiment to check the wear of the cutting tool at high-speed cutting of steel with a hardness of $63 \mathrm{HRC}$. milling

Study of wear on the cutting tool at high speed

SGS is used tool Series Power-Carb coated with AlTiN and tooth 6, wherein the treatment is performed with circular interpolation. Control program is implemented with the help of parameters and cycles meeting certain logical conditions. At the beginning of the control program introduces parameters such as diameter and height of the workpiece feeding speeds jutting out into the addition and routing, cross-filing and more. After each pass of 5 instrument is measuring its radius. Fig. 6 shows the control program.

0 BEGIN PGM M400 MM

1 FN 0: Q1 $=+156$

2 FN 0: Q2 $=+300$

3 FN 0: Q3 $=+152$

4 FN 0: Q4 $=+0.25$

5 FN 0: Q5 $=+0$

6 FN 0: Q6 $=+0$

7 FN 0: $\mathrm{Q} 7=+0$

8 FN 0: $\mathrm{Q} 8=+5$

9 FN 0: Q9 $=+4$

10 FN 0: Q10 $=+3000$

11 FN 0: Q11 $=+3000$

12 FN 0: Q12 $=+6000$

13 FN 0: Q13 $=+0$

14 FN 4: Q14 =+Q1 DIV +2

15 BLK FORM 0.1 Z X-Q14 Y-Q14 Z-Q2

16 BLK FORM $0.2 \quad \mathrm{X}+\mathrm{Q} 14 \quad \mathrm{Y}+\mathrm{Q} 14 \mathrm{Z}+0$

17 TOOL CALL 2 Z SQ12

18 LBL "IZMERVANE"

19 TCH PROBE 482 CAL. TOOL RADIUS Q340 $=+1 \quad ; \mathrm{CHECK}$

Q260 $=+100 ;$ CLEARANCE HEIGHT

Q341 $=+1 \quad$;PROBING THE TEETH

$20 \mathrm{~L} \mathrm{X+0} \mathrm{Y+0} \mathrm{Z+80} \mathrm{R0} \mathrm{FMAX}$

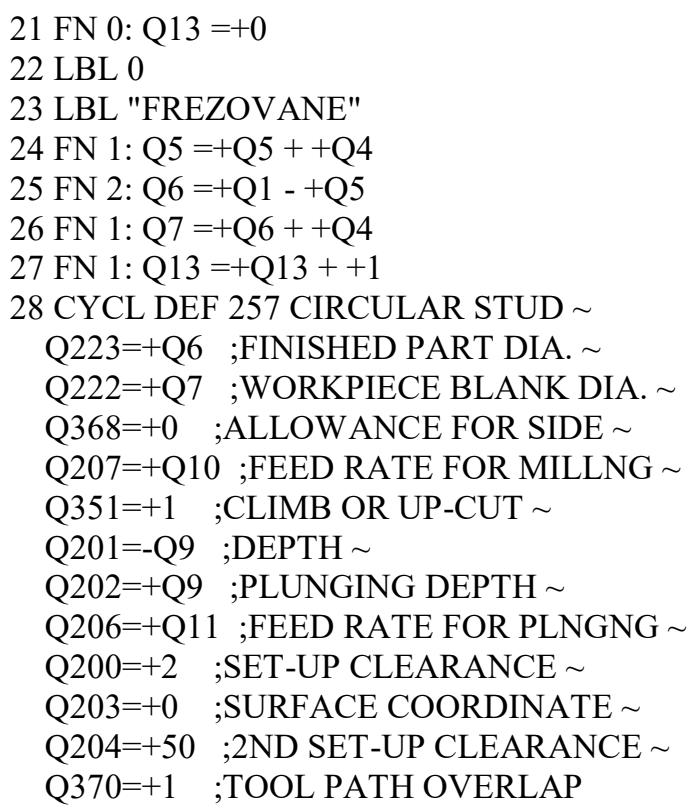

30 LBL 0

31 FN 15: PRINT Q108 /Q7 /Q5 /Q6 /Q13

32 FN 9: IF +Q13 EQU +Q8 GOTO LBL "IZMERVANE"

33 FN 11: IF +Q6 GT +Q3 GOTO LBL "FREZOVANE"

\section{END PGM M400 MM}

Fig. 6 Control program

The study was realized, it was made five attempts to change the regime of cutting. In Table. 3 shows the results of well skilled in mode 1 cutting: cut feed $3000 \mathrm{~mm} / \mathrm{min}$ (feed per tooth $0.083 \mathrm{~mm}$ ), spindle speed $6000 \mathrm{~min}-1$, step over $0.25 \mathrm{~mm}$, diameter of the workpiece $\mathrm{Dw}=158.85 \mathrm{~mm}$.

Table 3

Result of Experiment

\begin{tabular}{|c|c|c|c|}
\hline \multicolumn{4}{|c|}{ Experiment 1 } \\
\hline $\begin{array}{c}\text { Tool } \\
\text { radius, } \\
{[\mathrm{mm}]}\end{array}$ & $\begin{array}{c}\text { DR, } \\
{[\mathrm{mm}]}\end{array}$ & Dw, $[\mathrm{mm}]$ & $\begin{array}{c}\text { Distance L, } \\
{[\mathrm{mm}]}\end{array}$ \\
\hline \multirow{4}{*}{4} & & 158.6 & 498.2566 \\
\cline { 2 - 4 } & & 158.35 & 497.4712 \\
\cline { 2 - 4 } & & 158.1 & 496.6858 \\
\cline { 2 - 4 } & $\mathbf{0 . 0 1 4 7}$ & 157.85 & 495.9004 \\
\hline \multirow{3}{*}{} & & $\mathbf{1 5 7 . 6}$ & 495.1150 \\
\cline { 2 - 4 } & & Wear, $[\mathrm{mm}]$ & $\mathbf{2 4 8 3 . 4 2 9 0}$ \\
\cline { 3 - 4 } & & & $\mathbf{0 . 0 0 2 6}$ \\
\hline
\end{tabular}

A negative sign is accidentally received and due to the dissipation of the measurement results with Tool Setter TT140.

Experiment 2 was conducted in the following mode: cut feed $2000 \mathrm{~mm} / \mathrm{min}$ (feed per tooth 0.055), spindle speed $6000 \mathrm{~min}-1$, step over $0.32 \mathrm{~mm}$, diameter of the workpiece $\mathrm{Dw}=157,6 \mathrm{~mm}$ (Table. 4 ) 
Table 4

Result of Experiment 2

\begin{tabular}{|c|c|c|c|}
\hline \multicolumn{4}{|c|}{ Experiment 2 } \\
\hline $\begin{array}{c}\text { Tool } \\
\text { radius, } \\
{[\mathrm{mm}]}\end{array}$ & $\begin{array}{c}\text { DR, } \\
{[\mathrm{mm}]}\end{array}$ & Dw, $[\mathrm{mm}]$ & $\begin{array}{c}\text { Distance L, } \\
{[\mathrm{mm}]}\end{array}$ \\
\hline \multirow{4}{*}{4} & & 157.28 & 494.1097 \\
\cline { 2 - 4 } & & 156.96 & 493.1044 \\
\cline { 2 - 4 } & & 156.64 & 492.0991 \\
\cline { 2 - 4 } & $\mathbf{0 . 0 1 4 7}$ & 156.32 & 491.0938 \\
\hline \multirow{2}{*}{} & & $\mathbf{1 5 6 . 0 0}$ & 490.0884 \\
\cline { 2 - 4 } & & Wear, $[\mathrm{mm}]$ & $\mathbf{2 4 6 0 . 4 9 5 4}$ \\
\cline { 2 - 4 } & & & 0.0059 \\
\hline
\end{tabular}

Experiment 3 was conducted in the following mode: cut feed $3000 \mathrm{~mm} / \mathrm{min}$ (feed per tooth 0.083 ), spindle speed $6000 \mathrm{~min}-1$, step over $0.25 \mathrm{~mm}$, diameter of the workpiece $\mathrm{Dw}=156 \mathrm{~mm}$ (Table. 5 )

Table 5

Result of Experiment 3

\begin{tabular}{|c|c|c|c|c|}
\hline \multicolumn{5}{|c|}{ Experiment 3} \\
\hline $\begin{array}{c}\text { Tool } \\
\text { radius, } \\
\text { [mm] }\end{array}$ & $\begin{array}{l}\text { DR, } \\
{[\mathrm{mm}]}\end{array}$ & $\begin{array}{l}\text { Dw, } \\
{[\mathrm{mm}]}\end{array}$ & $\begin{array}{c}\text { Distance L, } \\
\text { [mm] }\end{array}$ & $\begin{array}{l}\text { Wear } \\
{[\mathrm{mm}]}\end{array}$ \\
\hline \multirow{4}{*}{ [ } & 0.0201 & 157.28 & 2434.73 & -0.0005 \\
\hline & 0.0231 & 156.96 & 2419.03 & 0.003 \\
\hline & \multicolumn{2}{|c|}{$\sum L,[\mathrm{~mm}]$} & 4853.76 & \\
\hline & \multicolumn{3}{|c|}{ Wear, [mm] } & 0.0025 \\
\hline
\end{tabular}

Experiment 4 - mode: cut feed $3000 \mathrm{~mm} / \mathrm{min}$ (feed per tooth 0.071), spindle speed $7000 \mathrm{~min}-1$, step over $0.25 \mathrm{~mm}$, feed per tooth 0.055 , diameter of the workpiece Dw $=153.25 \mathrm{~mm}$ (Table. 6)

Table 6

Result of Experiment 4

\begin{tabular}{|c|c|c|c|}
\hline \multicolumn{4}{|c|}{ Experiment 4} \\
\hline $\begin{array}{l}\text { Tool radius, } \\
\text { [mm] }\end{array}$ & DR, [mm] & $\begin{array}{c}\text { Distance } \mathbf{L}, \\
{[\mathrm{mm}]}\end{array}$ & $\begin{array}{l}\text { Wear } \\
{[\mathrm{mm}]}\end{array}$ \\
\hline \multirow[t]{8}{*}{4} & 0.0268 & 4684.9 & 0.0043 \\
\hline & 0.0273 & 3691.37 & 0.0005 \\
\hline & 0.0282 & 5061.89 & 0.0009 \\
\hline & 0.0299 & 4983.35 & 0.0017 \\
\hline & 0.0305 & 4904.81 & 0.0006 \\
\hline & 0.0318 & 4826.27 & 0.0016 \\
\hline & 0.0363 & 8347.99 & 0.0013 \\
\hline & 0.0394 & 8093.52 & 0.0048 \\
\hline \multicolumn{2}{|c|}{$\sum L,[\mathrm{~mm}]$} & 51733.36 & \\
\hline \multicolumn{3}{|c|}{ Wear, [mm] } & 0.0163 \\
\hline
\end{tabular}

In the last 5 Experiment was changed only step over $=0.15 \mathrm{~mm}$. The results are shown in Table. 7

Table 7

Result of Experiment 5

\begin{tabular}{|c|c|c|c|}
\hline \multicolumn{3}{|c|}{ Experiment 5 } \\
\hline $\begin{array}{c}\text { Tool } \\
\text { radius, } \\
{[\mathrm{mm}]}\end{array}$ & $\begin{array}{c}\text { DR, } \\
{[\mathrm{mm}]}\end{array}$ & Distance L, [mm] & $\begin{array}{c}\text { Wear } \\
{[\mathrm{mm}]}\end{array}$ \\
\hline 4 & 0.0407 & 4384.87 & 0.0013 \\
\hline$\sum L,[\mathrm{~mm}]$ & 4384.87 & \\
\hline \multicolumn{2}{|c|}{ Wear, $[\mathrm{mm}]$} & & 0.0013 \\
\hline
\end{tabular}

When the last attempt tool was completely worn out. In the treated surface was obtained yellowishbrown mark (fig. 7), from which it is clear that the tool is worn. This path is obtained by burning the material in the cutting zone. Fig. 8 is visible wear of the tool.

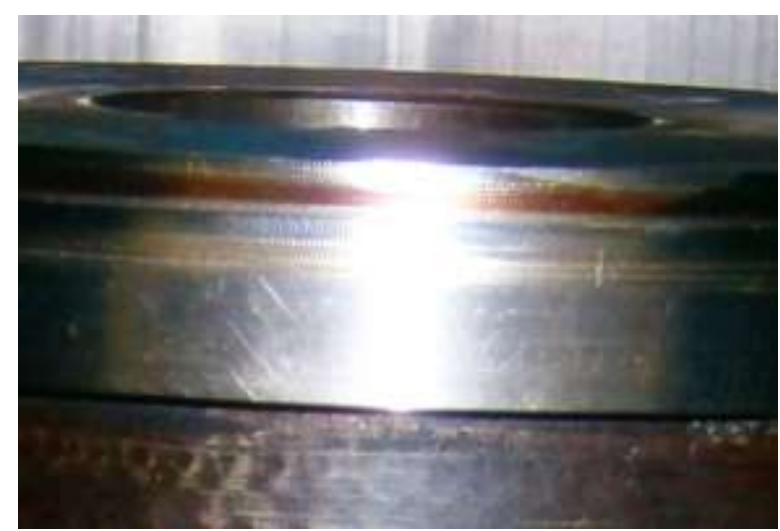

Fig. 7 Marks on the treated surface related to tool wear

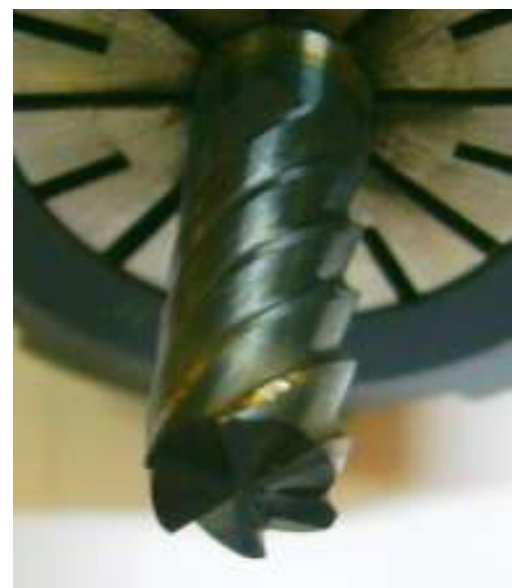

Fig. 8 Wear the instrument after completion of the study

The results of the experiment are summarized in Table. 8. From these data it is clear that the parameters used tool travels nearly 66 meters before being completely worn out.

Table 8

Summarized Results of the Study

\begin{tabular}{|c|c|}
\hline Total distance, $[\mathrm{mm}]$ & $\mathbf{6 6 0 0 0}$ \\
\hline Total wear, $[\mathrm{mm}]$ & $\mathbf{0 . 0 2 3 4}$ \\
\hline
\end{tabular}

Fig. 9 is a graph of tool wear compared traveled road. The amount of volume of the milled material is $45492 \mathrm{~mm}^{3}$. 
Environment. Technology. Resources, Rezekne, Latvia Proceedings of the $11^{\text {th }}$ International Scientific and Practical Conference. Volume III, 117-121

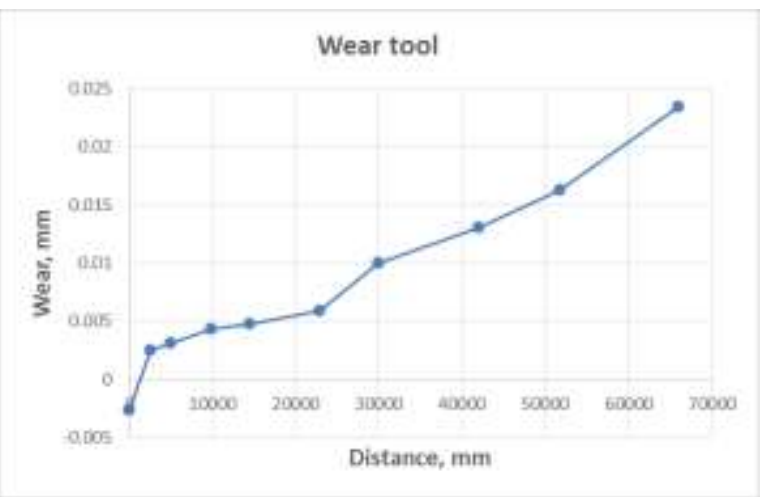

Fig. 9 Wear the instrument to the covered distance

\section{CONCLUSION}

From the results can be drawn the following conclusions:

1. In high-speed milling filled with these modes, tool wear is minimal compared to the distance covered;

2. From Fig. 9 it can be seen that with some initial wear, there is a slow minimum wear increase as compared to the way traveled. It is explained by the fact that in the initial stage of operation the wear of the tool is more intense and it is not in line with the way traveled;
3. Wear compared to the distance covered is negligible, and the life of the tool is much longer than prescribed by the manufacturer;

4. High-speed milling can replace the grinding operation at sharpening the cutting edge of the rotary die;

5. With high-speed milling, productivity increases about 2-3 times compared to grinding.

\section{REFERENCES}

[1] Хаджийски П., Маринов Ив., Анализ на износването на режещият клин на ротационни щанцови инструменти със сложна форма. 25-та Юбилейна научна конференция, МТФ, 2007, Созопол.

[2] Hadzhiyski P., Knives for rotary dies with variable geometry, Проблемы машиностроения и автоматизации, 2011, №4, стр. 132-136, ISSN 0234-6206.

[3] Хаджийски П., Анализ на възможностите за повишаване на производителността при шлифоване на режещи ръбове със сложна геометрия върху металорежещи машини с $\mathrm{CNC}$, Тринадесета национална научнотехническа конференция „Автоматизация на дискретното производство“ АДП 2004 г., София, стр. 6062, ISSN 1310-3946.

[4] SGS High Performance Catalog.

[5] www.sgstool.com.

[6] User's manual Heidenhain Conversational format, 2002 